\title{
Hubungan Aktivitas Fisik dengan Kadar Kolesterol Total, Kolesterol Low- Density Lipoprotein, dan Kolesterol High-Density Lipoprotein pada Masyarakat Jatinangor
}

\author{
Siti Fatimah Zuhroiyyah', Hadyana Sukandar², Sunaryo Barki Sastradimaja ${ }^{3}$ \\ ${ }^{1}$ Fakultas Kedokteran Universitas Padjadjaran, \\ ${ }^{2}$ Departemen Ilmu Kesehatan Masyarakat, Fakultas Kedokteran Universitas Padjadjaran, \\ ${ }^{3}$ Departemen Ilmu Kedokteran Fisik dan Rehabilitasi Medik, Fakultas Kedokteran Universitas Padjadjaran/ \\ Rumah Sakit Umum Pusat Hasan Dr. Sadikin Bandung, Indonesia
}

\begin{abstract}
Abstrak
Saat ini aktivitas fisik pada masyarakat semakin menurun. Untuk melakukan aktivitas fisik, manusia memerlukan energi yang didapat dari makanan. Jika pemakaian energi menurun, maka makanan yang harusnya dibentuk menjadi energi akan diubah menjadi kolesterol. Sudah banyak penelitian yang dilakukan untuk mengetahui hubungan aktivitas fisik dengan kadar kolesterol, namun hasil penelitiannya beragam. Oleh karena itu, dilakukan penelitian untuk mengetahui hubungan aktivitas fisik dengan kadar kolesterol total, Low Denstiy Lipoprotein (LDL), dan High Density Lipoprotein (HDL) pada masyarakat Jatinangor. Penelitian ini merupakan bagian dari penelitian "Epidemiologi Hipertensi dan Albuminuria di Jatinangor". Penelitian analitik dengan desain potong lintang melibatkan 120 orang dari 3 strata desa, yaitu urban, semirural, dan rural, di Jatinangor. Variabel yang diteliti terdiri dari jenis kelamin, usia, indeks massa tubuh, aktivitas fisik, kadar kolesterol total, LDL, dan HDL. Data dianalisis dengan menggunakan perhitungan korelasi rank Spearman. Aktivitas fisik memiliki hubungan terbalik yang bermakna dengan kadar kolesterol total dan LDL dengan nilai $r=-0,302(p=0,001)$ dan $\mathrm{r}=-0,288(\mathrm{p}=0,001)$. Sedangkan aktivitas fisik tidak memiliki hubungan yang bermakna dengan kadar kolesterol HDL $r=0,090(p=0,328)$. Kesimpulan aktivitas fisik memiliki hubungan dengan kadar kolesterol total dan LDL. Sedangkan aktivitas fisik tidak memiliki hubungan dengan kadar kolesterol HDL pada masyarakat Jatinangor
\end{abstract}

Kata kunci : Aktivitas fisik, Kolesterol HDL, Kolesterol LDL, Kolesterol Total

\section{Relationship Between Physical Activity with Total, Low-Density Lipoprotein, and High-Density Lipoprotein Cholesterol Level in Jatinangor Community}

\begin{abstract}
Recently, there has been a deteriorating physical activity in the society. To do a physical activity, human requires energy obtained from food intake. If the energy expenditure decreases, the foods that supposed to be converted into energy will be stored as cholesterol. There were several studies that have been conducted to analyze the relationship between physical activity and cholesterol level. However, the results varied. Therefore, this study was conducted to analyze the relationship between physical activity with total cholesterol, low density lipoprotein $(L D L)$ and high density lipoprotein (HDL) level in Jatinangor community. This study belongs to the "Epidemiologi Hipertensi dan Albuminuria di Jatinangor" research. An analytical cross-sectional study design involving 120 subjects from three strata of village, including urban, semirural and rural area in Jatinangor was used in this study. The studied variables consisted of gender, age, body mass index, physical activity, total cholesterol, LDL and HDL levels. The data were analyzed using Spearman's rank-order correlation formula. The result revealed that there was a significant negative relationship between physical activity with total cholesterol and LDL levels, with $r=-0,302(p=0,001)$ and $r=-0,288(p=0,001)$. However, there was no significant relationship between physical activity and HDL cholesterol levels, with $r=0,090(p=0,328)$. Physical activity has a relationship with total and LDL cholesterol level. Meanwhile there was no relationship with HDL cholesterol level in Jatinangor community
\end{abstract}

Keywords: HDL cholesterol, LDL cholesterol, Physical activity, Total cholesterol

Korespondensi:

Siti Fatimah Zuhroiyyah

Fakultas Kedokteran Universitas Padjadjaran

Jl. Raya Bandung-Sumedang KM 21 Jatinangor, Sumedang

Mobile : 085722409039

Email : sitifatimahzuhroiyyah@gmail.com 


\section{Pendahuluan}

Dalam era moderen ini banyak dilakukan penemuan teknologi baru untuk membantu pekerjaan manusia agar menjadi lebih ringan, mudah, dan cepat dikerjakan. Terdapat sisi negatif dari perkembangan teknologi ini yakni dalam hal aktivitas fisik, semakin maju dan canggihnya teknologi yang digunakan maka aktivitas fisik yang dilakukan setiap harinya semakin berkurang. ${ }^{1,2}$ Menyikapi hal ini, pemerintah menetapkan aktivitas fisik menjadi salah satu indikator dari 10 indikator perilaku hidup bersih dan sehat (PHBS) dan salah satu pilar dari 4 pilar gizi seimbang. ${ }^{3,4}$

Menurut World Health Organization (WHO) yang dimaksud aktivitas fisik adalah gerakan tubuh yang dihasilkan oleh otot rangka yang memerlukan pengeluaran energi. Energi ini didapatkan dari makanan yang dikonsumsi. Pola makan dan aktivitas fisik dapat menentukan kadar kolesterol di dalam tubuh. Makanan yang dikonsumsi akan mengalami proses metabolisme dan menghasilkan adenosin triphosphate (ATP). ATP ini merupakan energi untuk melakukan aktivitas fisik. Pembentukan ATP ini disesuaikan dengan kebutuhan, sehingga tidak semua makanan yang dikonsumsi akan diubah langsung menjadi ATP melainkan ada yang disimpan dalam bentuk kolesterol. Semakin banyak aktivitas fisik yang dilakukan maka akan semakin banyak kebutuhan ATP dan akan menyebabkan sedikitnya pembentukan kolesterol total dan kolesterol Low-Density Lipoprotein (LDL) serta peningkatan kolesterol High-Density Lipoprotein (HDL) ${ }^{5,6}$

Sudah banyak penelitian di tingkat nasional maupun internasional yang berkaitan dengan aktivitas fisik dan kadar kolesterol, namun masih banyak kontroversi, karena memiliki hasil penelitian yang berbeda-beda, ada yang menyatakan terdapat hubungan yang signifikan dan ada juga yang menyatakan hubungan antara aktivitas fisik dengan kadar kolesterol tidak signifikan. Sebagai contoh pada penelitian yang dilakukan oleh Jamshid Hoshain-Alizadeh pada tahun 2014 dan Carla Guiliano pada tahun 2015 menyatakan keterkaitan antara aktivitas fisik dengan kadar kolesterol dinilai signifikan. Sedangkan pada penelitian yang dilakukan oleh Blanca Romero pada tahun 2013 menyatakan bahwa hubungan antara aktivitas fisik dengan kadar kolesterol dinilai tidak signifikan..$^{7-9}$

Walaupun sudah banyak penelitian yang dilakukan, namun belum ada peneliti yang melakukan penelitian di Jatinangor mengenai keterkaitan antara aktivitas fisik dengan kadar kolesterol total, kolesterol LDL, dan kolesterol
HDL. Maka dari itu, penelitian ini perlu diadakan untuk mengetahui hubungan antara aktivitas fisik dengan kadar kolesterol total, kolesterol low-density lipoprotein, dan kolesterol highdensity lipoprotein pada masyarakat Jatinangor. Penelitian ini merupakan bagian dari penelitian yang diadakan oleh pusat studi kesehatan kebugaran komunitas (K3) dengan judul "Epidemiologi Hipertensi dan Albuminuria di Jatinangor".

\section{Metode}

Penelitian ini menggunakan desain analitik dengan pendekatan studi potong lintang dan menggunakan data sekunder dari penelitian "Epidemiologi Hipertensi dan Albuminuria di Jatinangor". Subjek penelitian ini mewakili tiga strata desa yaitu Cipacing yang mewakili strata desa urban, Hegarmanah mewakili strata semirural, dan Cilayung mewakili strata rural. Penentuan ukuran sampel ditentukan berdasarkan rumus korelasi dengan menetapkan taraf signifikansi $5 \%$ dan power tes $80 \%$ serta besarnya koefisien korelasi (r) diambil dari penelitian serupa yang pernah dilakukan sebelumnya, untuk kolesterol total $r=-0,463$, untuk kolesterol LDL $r=-0,468$, dan untuk kolesterol HDL $r=0,385$. Dari hasil perhitungan, didapat minimal sampel untuk kadar kolesterol total 32 orang, kolesterol LDL 31 orang, dan kolesterol HDL 47 orang. Dari data penelitian "Epidemiologi Hipertensi dan Albuminuria di Jatinangor" dipilih sampel penelitian yang memenuhi kriteria inklusi dan eksklusi. Berdasarkan Badan Kependudukan dan Keluarga Berencana Nasional (BKKBN) bahwa usia 15 - 59 tahun merupakan usia yang produktif, dan menurut American Heart Association bahwa usia $\geq 20$ tahun sudah berisiko untuk terjadinya perubahan kadar kolesterol di dalam tubuh, sehingga pada penelitian ini kriteria inklusi responden yang diikutsertakan memiliki rentang usia 20 - 59 tahun, sedangkan untuk kriteria eksklusinya adalah responden yang datanya tidak lengkap dan atau memiliki kecacatan fisik. Penelitian ini dilakukan dari bulan Agustus sampai bulan November 2016.

Variabel pada penelitian ini terbagi menjadi tiga, yaitu variabel bebas, terikat, dan variabel perancu. Variabel bebas pada penelitian ini adalah aktivitas fisik yang diukur dengan Global Physical Activity Questionnaire (GPAQ) yang dikeluarkan oleh World Health Organization (WHO) dan sudah diterjemahkan kedalam bahasa Indonesia. Di dalam GPAQ terdapat 16 pertanyaan yang menggambarkan tiga jenis kondisi yaitu aktivitas pekerjaan, aktivitas perjalanan, dan 
aktivitas rekreasi. Aktivitas fisik diklasifikasikan berdasarkan waktu untuk melakukan aktivitas fisik dan total of metabolic equivalent (MET)-menit dalam 1 minggu, aktivitas fisik dikategorikan cukup bila responden melakukan aktivitas fisik dengan intensitas sedang selama 150 menit dalam 1 minggu, atau melakukan aktivitas dengan intensitas berat selama 75 menit dalam 1 minggu, atau kombinasi aktivitas fisik sedang dan berat yang minimal mencapai 600 MET-menit dalam 1 minggu, sedangkan aktivitas dikategorikan kurang bila responden tidak memenuhi kriteria kategori aktivitas cukup. ${ }^{10}$ Adapun variabel terikat dalam penelitian ini adalah kadar kolesterol total, kolesterol LDL, dan kolesterol HDL. Kadar kolesterol diukur dengan uji laboratorium Departemen Patologi Klinik Rumah Sakit Pendidikan Hasan Sadikin Bandung. Kadar kolesterol dikategorikan berdasarkan klasifikasi Adult Treatment Panel (ATP) III menjadi tiga kategori yaitu optimal jika kadar kolesterol total $<200 \mathrm{mg} / \mathrm{dL}$, batas tinggi jika kadar kolesterol total $200-239 \mathrm{mg} / \mathrm{dL}$, dan tinggi jika kadar kolesterol total $\geq 240 \mathrm{mg} / \mathrm{dL}$, untuk kadar kolesterol LDL yaitu optimal jika kadarnya $<100 \mathrm{mg} / \mathrm{dL}$, batas tinggi jika kadarnya $100-159 \mathrm{mg} / \mathrm{dL}$, dan tinggi jika kadarnya $\geq 160$ $\mathrm{mg} / \mathrm{dL}$, untuk kadar kolesterol HDL yaitu rendah jika kadarnya $<40 \mathrm{mg} / \mathrm{dL}$, baik/sedang jika kadarnya $40-59 \mathrm{mg} / \mathrm{dL}$, dan tinggi jika kadarnya $\geq 60 \mathrm{mg} / \mathrm{dL}$.

Pada penelitian ini terdapat tiga variabel perancu yaitu jenis kelamin, usia yang dikategorikan menjadi 4 kategori dengan interval 10 tahun yaitu usia $20-29$ tahun, usia $30-39$ tahun, usia 40 - 49 tahun, usia 50 - 59 tahun, dan indeks massa tubuh yang diklasifikasikan berdasarkan kriteria Departemen Kesehatan (Depkes) tahun 2010 yaitu kurus jika indeks massa tubuh $<18,5 \mathrm{~kg} / \mathrm{m}^{2}$, normal jika indeks massa tubuh $18,5-25,0 \mathrm{~kg} / \mathrm{m}^{2}$, dan gemuk jika indeks massa tubuh $\geq 25,1 \mathrm{~kg} / \mathrm{m}^{2}$.

Data hasil penelitian diolah dan dianalisis secara deskriptif, dengan menyajikan ukuran jumlah dan persentase untuk data kategorik, sedangkan untuk data numerik dengan menghitung rerata, standar deviasi, median dan rentang. Untuk analitik dengan menggunakan perhitungan korelasi rank Spearman. Kemaknaan korelasinya ditentukan berdasarkan nilai $\mathrm{p}<0,05$.

Penelitian ini sudah disetujui oleh komite etik penelitian Fakultas Kedokteran Universitas Padjadjaran No:47/UN6.C1.3.2/KEPK/PN/2016.

\section{Hasil}

Terdapat 1254 data dari penelitian "Epidemiologi Hipertensi dan Albuminuria di Jatinangor", namun yang memenuhi kriteria inklusi dan eksklusi sebanyak 120 data responden.

Tabel 1 menyajikan data karakteristik subjek dan berbagai variabel yang diteliti. Dari data tersebut status gizi yang diukur dengan indeks massa tubuh bervariasi dari kurus ke gemuk.

Tabel 2 menyajikan data deskriptif statistik dari masing-masing variabel yang memiliki skala numerik yang terdapat pada penelitian ini. Dari tabel tersebut, aktivitas fisik dibagi dalam dua kategori yaitu kurang dan cukup.

Tabel 1 Karakteristik Responden $(\mathbf{n}=\mathbf{1 2 0})$

\begin{tabular}{ccc}
\hline Karakteristik Responden & Jumlah & $\mathbf{\%}$ \\
\hline Jenis Kelamin & 38 & 31,7 \\
Laki - laki & 82 & 68,3 \\
Perempuan & & \\
Usia (tahun) & 3 & 2,5 \\
$20-29$ & 16 & 13,3 \\
$30-39$ & 44 & 36,7 \\
$40-49$ & 57 & 47,5 \\
$50-59$ & & \\
Kurus $(<18,5)$ & 10 & 8,3 \\
Normal $(18,5-25,0)$ & 49 & 40,8 \\
Gemuk $(\geq 25,1)$ & 61 & 50,8 \\
\hline
\end{tabular}


Siti Fatimah Zuhroiyyah : Hubungan Aktivitas Fisik dengan Kadar Kolesterol Total, Kolesterol Low-Density Lipoprotein, dan Kolesterol High-Density Lipoprotein pada Masyarakat Jatinangor

Tabel 2 Deskriptif Statistik Aktivitas Fisik, Kolesterol Total, LDL, dan HDL Responden

\begin{tabular}{|c|c|c|c|c|}
\hline \multirow{2}{*}{ Variabel } & \multicolumn{3}{|c|}{ Deskriptif Statistik } & \multirow{2}{*}{ Kategori } \\
\hline & $\mathrm{X}(\mathrm{SD})$ & Median & Rentang & \\
\hline \multirow[t]{3}{*}{ Aktivitas fisik (MET-menit) } & $2801,5(5409,9)$ & 1200,0 & $120-26880$ & Kurang $(38,3 \%)$ \\
\hline & & & & Cukup $(61,7 \%)$ \\
\hline & & & & Optimal ( $60,0 \%)$ \\
\hline \multirow[t]{3}{*}{ kadar kolesterol total (mg/dL) } & $195,5(40,9)$ & 192,0 & $111-310$ & Batas Tinggi $(25,8 \%)$ \\
\hline & & & & Tinggi $(14,2 \%)$ \\
\hline & & & & Optimal ( $17,5 \%)$ \\
\hline \multirow[t]{3}{*}{ kadar kolesterol LDL (mg/dL) } & $128,5(35,2)$ & 124,5 & $39-240$ & Batas Tinggi $(64,2 \%)$ \\
\hline & & & & Tinggi $(18,3 \%)$ \\
\hline & & & & Rendah ( 47,5\%) \\
\hline \multirow[t]{2}{*}{ kadar kolesterol HDL (mg/dL) } & $42,3(13,6)$ & 40,0 & $17-86$ & Baik/sedang $(41,7 \%)$ \\
\hline & & & & Tinggi $(10,8 \%)$ \\
\hline
\end{tabular}

Tabel 3 Korelasi Aktivitas Fisik dengan Kadar Kolesterol Total, Kolesterol LDL, dan Kolesterol HDL

\begin{tabular}{lcc}
\hline \multicolumn{1}{c}{ Variabel antara } & Koefisien korelasi $(\mathbf{r})$ & Nilai $\mathbf{p}$ \\
\hline $\begin{array}{l}\text { Aktifitas Fisik dengan Kadar } \\
\text { Kolesterol Total }\end{array}$ & $-0,302$ & 0,001 \\
$\begin{array}{l}\text { Aktifitas Fisik dengan Kadar } \\
\text { Kolesterol LDL }\end{array}$ & $-0,288$ & 0,001 \\
$\begin{array}{l}\text { Aktifitas Fisik dengan Kadar } \\
\text { Kolesterol HDL }\end{array}$ & 0,090 & 0,328 \\
\hline Kel & & \\
\hline
\end{tabular}

Keterangan : $\mathrm{r}=$ koefisien korelasi rank Spearman Bermakna jika $\mathrm{p}<0,05$

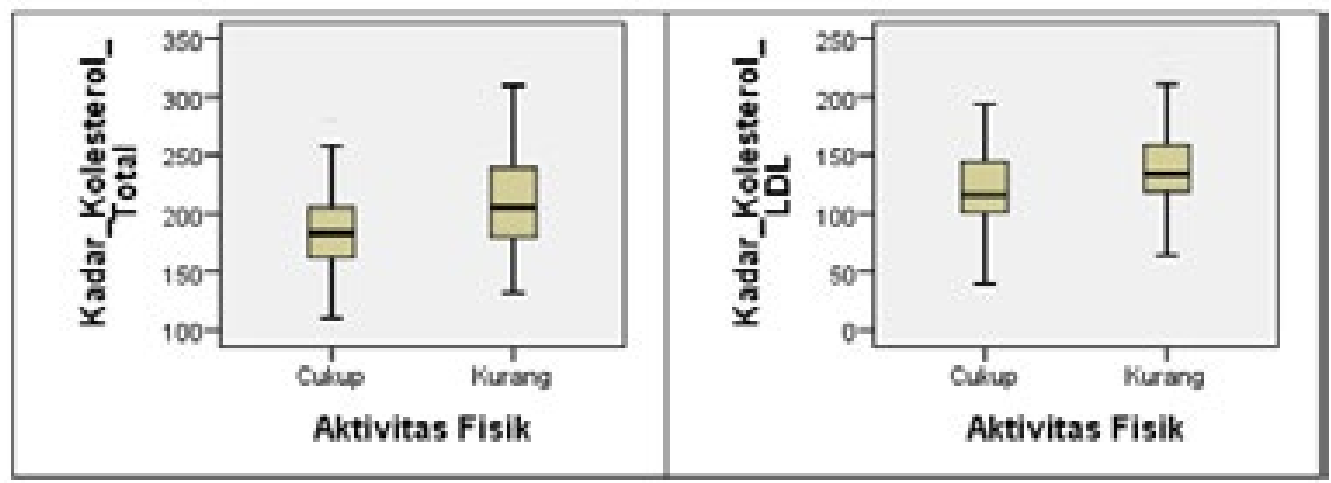

Gambar 1 Hubungan Aktivitas Fisik dengan Kadar Kolesterol Total, dan LDL 
Gambaran profil lipid untuk kadar kolesterol total yang paling banyak adalah kategori optimal dan kadar tertingginya adalah $310 \mathrm{mg} / \mathrm{dL}$, untuk kolesterol LDL kategori terbanyak adalah batas tinggi dan kadar tertingginya $240 \mathrm{mg} / \mathrm{dL}$, sedangkan untuk kadar kolesterol HDL kategori terbanyaknya adalah rendah dengan nilai terendahnya $17 \mathrm{mg} / \mathrm{dL}$. Dari data yang disajikan pada tabel 3 bahwa aktivitas fisik memiliki hubungan yang berbanding terbalik dengan kadar kolesterol total dan LDL, dan hubungannya dinilai bermakna, sedangkan aktivitas fisik tidak memiliki hubungan yang bermakna dengan kadar kolesterol HDL.

Pada gambar 1 menyajikan gambaran bahwa responden yang memiliki aktivitas fisik dengan kategori cukup memiliki kadar kolesterol total yang lebih rendah dibandingkankan responden yang memiliki aktivitas fisik dengan kategori kurang. Gambar 2 menyajikan gambaran bahwa responden yang memiliki aktivitas fisik dengan kategori cukup memiliki kadar kolesterol LDL yang lebih rendah dibandingkankan responden yang memiliki aktivitas fisik dengan kategori kurang.

Tabel 4 menyajikan hubungan aktivitas fisik dengan kadar kolesterol total, kolesterol LDL, dan kolesterol HDL setelah dikontrol dengan variabel perancu, hasilnya menunjukkan hubungan yang lebih kuat antara aktivitas fisik dengan kadar kolesterol total dan kolesterol LDL dengan koefisien korelasi masing-masing $r=-0,349(p<0,001)$ dan $r=-0,313(p=0,001)$.

\section{Pembahasan}

Pada penelitian ini menggunakan 120 data yang memenuhi kriteria inklusi dan eksklusi dari 1254 data yang tersedia di penelitian "Epidemiologi Hipertensi dan Albuminuria di Jatinangor".

Dari hasil analisis korelatif, peneliti mendapatkan tiga hasil. Hasil yang pertama, aktivitas fisik memiliki hubungan yang terbalik

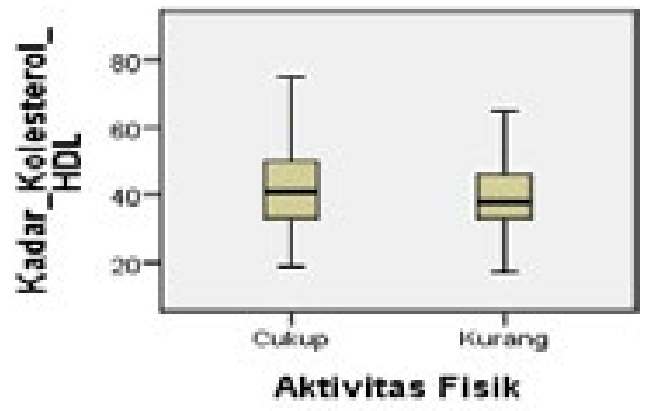

Gambar 2 Hubungan Aktivitas Fisik dengan Kadar Kolesterol HDL

Tabel 4 Korelasi Aktivitas Fisik dengan Kadar Kolesterol Total, Kolesterol LDL, dan Kolesterol HDL dikontrol oleh Variabel Perancu

\begin{tabular}{cccc}
\hline Faktor yang dikontrol & Variabel antara & Koefisien korelasi (r) & Nilai p \\
\hline & $\begin{array}{c}\text { Aktifitas Fisik dengan Kadar } \\
\text { Kolesterol Total }\end{array}$ & $-0,349$ & $<0,001$ \\
$\begin{array}{c}\text { Jenis Kelamin, Usia, Indeks } \\
\text { Massa Tubuh (IMT) }\end{array}$ & $\begin{array}{c}\text { Aktifitas Fisik dengan Kadar } \\
\text { Kolesterol LDL } \\
\text { Aktifitas Fisik dengan Kadar } \\
\text { Kolesterol HDL }\end{array}$ & $-0,313$ & 0,001 \\
$\begin{array}{c}\text { Keterangan : r= koetisien korelasi rank Spearman } \\
\text { Bermakna jika p p }<0,05 \quad 0,029\end{array}$ & 0,759
\end{tabular}


dengan kadar kolesterol total dengan nilai koefisien korelasinya $-0,302$ dan nilai $\mathrm{p}=0,001$ yang menunjukkan bahwa hubungannya bermakna. Hasil penelitian ini sejalan dengan teori, bahwa ketika melakukan aktivitas fisik, tubuh akan melakukan pembetukan energi yang berupa adenosin triphosphate (ATP) dari makanan yang dikonsumsi. Sehingga makanan yang dikonsumsi tidak banyak dibentuk menjadi kolesterol, akibatnya kadar kolesterol total di dalam tubuh menurun. Hasil penelitian ini juga selaras dengan hasil penelitian yang dilakukan oleh Tunggul Waloya pada tahun 2013 dan penelitian yang dilakukan Paul D.Lopirinzi dan Ovuokerie Addoh pada tahun 2016, selain itu juga dijelaskan pada penelitian yang dilakukan Wanda Barbara Pilch tahun 2015 bahwa aktivitas fisik memiliki hubungan yang signifikan dengan kadar kolesterol total. ${ }^{11-13}$

Hasil yang kedua, aktivitas fisik memiliki hubungan yang berbanding terbalik dengan kadar kolesterol LDL dengan hasil nilai koefisien korelasinya $-0,288$ dan nilai $p=0,001$ yang menunjukkan bahwa hubungan antar variabel dinilai bermakna. Hal ini sejalan dengan teori bahwa setelah melalui proses pencernaan dan penyerapan, makanan akan mengalami pembentukan menjadi Acetyl-CoA yang selanjutnya memasuki siklus krebs untuk proses pembentukan ATP, sehingga proses pembentukan dan transportasi kolesterol ke seluruh tubuh akan menurun yang mengakibatkan kolesterol Low-Density Lipoprotein (LDL) sebagai alat transportasi kolesterol ke seluruh tubuh tidak banyak dibentuk, maka dari itu kadar kolesterol LDL menurun. Hasil penelitian ini selaras dengan penelitian yang dilakukan oleh S.Pooranfar, dkk pada tahun 2014 dan penelitian yang dilakukan Keri L. Monda dkk pada tahun 2009, selain itu hasil penelitian ini pun didukung oleh penelitian serupa yang dilakukan oleh Alexis C. FrazierWood pada tahun 2014. ${ }^{14-16}$

Hasil yang ketiga, aktivitas fisik tidak memiliki hubungan dengan kadar kolesterol HDL dengan $r$ $=0,090$ dan nilai $p>0,05$. Secara teori menyatakan bahwa ketika pembentukan ATP meningkat, maka tubuh akan mengkompensasi dengan cara pembentukan High-Density Lipoprotein (HDL). Pembentukan HDL ini dimaksudkan untuk memfasilitasi kolesterol berlebih di perifer dapat diangkut menuju hepar sebagai cadangan energi. Namun hasil penelitian ini menunjukkan bahwa aktivitas fisik tidak mempengaruhi kadar kolesterol HDL. Hasil penelitian ini selaras dengan hasil penelitian yang dilakukan oleh Jeroen SL de Munter pada tahun 2011 dan juga penelitian yang dilakukan oleh Anne H. Y.Chu dan Foong Ming Moy pada tahun 2013. ${ }^{17,18}$
Berdasarkan penelitian yang dilakukan oleh Raquel Caroline da Silva dkk pada tahun 2016 menyatakan bahwa kadar kolesterol HDL akan dipengaruhi oleh aktivitas fisik dengan kategori berat. Pada penelitian ini, aktivitas fisik hanya dikategorikan menjadi 2 yaitu aktivitas fisik cukup dan kurang. Selain itu, disebutkan dalam hasil penelitian yang dilakukan oleh Birsen Ucar pada tahun 2007 bahwa kadar kolesterol HDL dipengaruhi oleh jenis kelamin, yaitu kadar kolesterol HDL laki-laki lebih tinggi dari pada wanita. Pada penelitian yang dilakukan Birsen Ucar jumlah populasi yang diikutsertakan sebanyak 2896 yang terdiri dari 1467 perempuan dan 1429 laki-laki, sedangkan pada penelitian ini terdapat 120 responden yang terdiri dari 38 laki-laki dan 82 orang perempuan, yang menunjukkan bahwa perbandingan jumlah laki-laki dan perempuan yang sangat tidak seimbang. Oleh karena itu, peneliti berasumsi bahwa pada penelitian ini, aktivitas fisik dinilai tidak memiliki hubungan yang bermakna dengan kadar kolesterol HDL dikarenakan peneliti tidak mengetahui jenis aktivitas fisik dengan kategori ringan, sedang, berat yang paling banyak dilakukan oleh responden dan perbandingan jumlah antara sampel laki-laki dan perempuan yang sangat tidak seimbang. ${ }^{19,20}$

Adapun keterbatasan dari penelitian ini adalah peneliti tidak menganalis data pola makan responden yang merupakan salah satu faktor yang dapat mempengaruhi kadar kolesterol di dalam tubuh.

Simpulan dari penelitian ini adalah aktivitas fisik memiliki hubungan berbanding terbalik yang signifikan dengan kadar kolesterol total, dan kolesterol LDL pada masyarakat Jatinangor. Namun aktivitas fisik tidak memiliki hubungan yang signifikan dengan kadar kolesterol HDL pada masyarakat Jatinangor.

\section{Ucapan terimakasih}

Peneliti mengucapkan terimaksih kepada Prof. Dr. Rully M.A. Roesli, dr., SpPD-KGH., Yulia Sofiatin, dr., SpPD., dan semua supervisi yang tergabung dalam penelitian "Epidemiologi Hipertensi dan Albuminuria di Jatinangor" untuk semua kontribusinya dalam penyusunan artikel jurnal ini.

\section{Daftar Pustaka}

1. Oliveira-brochado ANA, Oliveira-brochado F, Brito PQ. Effects of personal, social and environmental factors on physical activity 
behavior among adults. Act Fis. 2010;28:718.

2. Effendi A, Prihanto JB. Pengaruh Penggunaan Teknologi Informasi Terhadap Aktivitas Fisik. J Pendidik Olahraga dan Kesehat. 2014;2(3):605-8. Tersedia dari:http;// ejournal.unesa.ac.id/index.php/jurnalpendidikanjasmani/issue/archive

3. Penelitian B, Pengembangan. Riset Kesehatan Dasar. Jakarta; 2013.

4. Menteri Kesehatan Republik Indonesia. Peraturan Menteri Kesehatan Republik Indonesia Tentang Pedoman Gizi Seimbang. 1110 Indonesia; $2014 \mathrm{hlm} .7,82$.

5. Rodwell V, Bender D, Botham K, Kennelly P, Weil A. Harper's Illustrated Biochemistry. 30th ed. Mc Graw Hill Education; 2015. hlm.212 - 221.

6. Whitney E, Rolfes SR. Understanding Nutrition. 14th ed. Cengage Learning; 2015. hlm.142 - 147.

7. Hosain-Alizadeh J, Goodarzi MT. Body Fat and Plasma Lipid Profile in Different Levels of Physical Fitness in Male Students. J Res Health Sci. 2014;14(3):214-7. Tersedia dari: www.umsha.ac.ir/jrhs

8. Pinto CG de S, Marega M, Carvalho JAM de, Carmona FG, Lopes CEF, Ceschini FL, dkk. Physical activity as a protective factor for development of non-alcoholic fatty liver in men. 2015;13(55 11):34-40.

9. Moraleda BR, Morencos E, Peinado AB, Bermejo L, Candela CG, Benito PJ, dkk. Can the exercise mode determine lipid profile improvements in obese patients ? Nutr Hosp. 2013;28(3):607-17.

10. World Health Organization. Global Physical Activity Questionnaire (GPAQ) Analysis Guide. 2012;1-23. Tersedia dari: www.who. int $/ \mathrm{chp} / \mathrm{steps}$

11. Waloya T, Rimbawan, Andarwulan N. Hubungan antara konsumsi pangan dan aktivitas fisik dengan kadar kolesterol darah pria dan wanita dewasa di Bogor. J Gizi dan Pangan. 2013;8(1):9-16.

12. Lopirinzi PD, Addoh O. The association of physical activity and cholesterol concentrations across different combinations of central adiposity and body mass index.
Heal Promot Perspect. 2016;6(3):128-36. Tersedia dari: http://journals.tbzmed.ac.ir/ HPP

13. Pilch WB, Mucha DM, Pałka TA, Suder AE, Piotrowska AM, Tyka AK, dkk. The influence of a 12-week program of physical activity on changes in body composition and lipid and carbohydrate status in postmenopausal women. 2015;14(4):231-7.

14. Pooranfar S, Shakoor E, Shafahi MJ, M.Salesi, Karimi MH, Roozbeh J, dkk. The Effect of Exercise Training on Quality and Quantity of Sleep and Lipid Profile in Renal Transplant Patients: A Randomized Clinical Trial. Int J Organ Transplant Med. 2014;5(4).

15. Monda KL, Ballantyne CM, North KE. Longitudinal impact of physical activity on lipid profiles in middle-aged adults : the Atherosclerosis Risk in Communities Study. J Lipid Res. 2009;50:1685-91. Tersedia dari: http;//www.jlr.org

16. Frazier-wood AC, Borecki IB, Feitosa MF, Hopkins PN, Smith CE, Arnett DK. SexSpecific Associations Between Screen Time and Lipoprotein Subfractions. Natl Inst Heal. 2015;24(1):59-69.

17. Munter JSL De, Valkengoed IG Van, Stronks $\mathrm{K}$, Agyemang C. Total physical activity might not be a good measure in the relationship with HDL cholesterol and triglycerides in a multi-ethnic population: a cross-sectional study. Lipids Health Dis. BioMed Central Ltd; 2011;10(1):223. Tersedia dari: http:// www.lipidworld.com/content/10/1/223

18. Chu AHY, Moy FM. Joint Association of Sitting Time and Physical Activity with Metabolic Risk Factors among Middle-Aged Malays in a Developing Country : A CrossSectional Study. PLoS One. 2013;8(4):1-7.

19. Caroline R, Fátima M De, Sander H, Alvim S, Vidigal PG, Maria L, dkk. Physical Activity and Lipid Profile in the ELSA- Brasil Study. Sociadade Bras Cardiol. 2016;10-9.

20. Ucar B, Zubeyir Kilic, Dinleyici EC, Colak $\mathrm{O}$, Gunes E. Serum lipid profiles including non-high density lipoprotein cholesterol levels in Turkish school-children. 2007;41520. 